\title{
On the distribution of $O$-seryl- $\mathrm{N}$-acetylgalactosaminide glycosidase and $N$-acetyl- $\beta$ - $D$-hexasaminidase in vertebrates and invertebrates
}

\author{
Huberta Schauer and Alfred Gottschalk \\ Max-Planck-Institut für Virusforschung, Tübingen \\ (Z. Naturforschg. 22 b, 1030-1032 [1967] ; eingegangen am 27. Juli 1967)
}

\begin{abstract}
The enzymes $O$-seryl- $N$-acetylgalactosaminide glycosidase and $N$-acetyl- $\beta$-D-hexosaminidase were found in the following invertebrates and vertebrates: Adamsia palliata, Mesostoma ehrenbergi, Bugula avicularia, Lumbricus terrestris, Pagurus prideauxi, Helix pomatia, Ciona intestinalis, Brachidanio albolineatus, Rana esculenta, chicken and ox. They were assayed by their action on neuraminic acid-free ovine submaxillary glycoprotein, which contains an $O$-seryl- $N$-acetylgalactosaminide linkage, and on phenyl $N$-acetyl- $\beta$-D-glucosaminide respectively. As previously shown for ox spleeen and Helix pomatia, also the two enzyme proteins present in the homogenates of chick embryo and Lumbricus terrestris eluted from Sephadex columns in two separate peaks.
\end{abstract}

It was reported previously ${ }^{1}$ that the supernatant of the homogenate of ox spleen contains two distinct hexosaminidases. One of them, the well established $N$-acetyl- $\beta$-D-hexosaminidase (EC 3.2.1.30.), splits off from oligosaccharides, prepared from hyaluronic acid and from chondroitin 4-sulphate by action of testicular hyaluronidase (EC 3.2.1.35) and $\beta$-D-glucuronidase (EC 3.2.1.31), $N$-acetylglucosamine and $N$-acetylgalactosamine respectively from the nonreducing terminal. Its enzymic activity is conveniently assayed using phenyl or $p$-nitrophenyl $N$-acetyl- $\beta$-D-glucosaminide as substrate.

The other hexosaminidase acts on NANA-free $\mathrm{OSM}^{*}$ and on glycopeptides prepared therefrom. In these compounds unsubstituted $N$-acetylgalactosamine residues are linked $O$-glycosidically to peptide-bonded serine and threonine residues. The enzyme cleaving this glycosidic linkage was tentatively termed $O$-seryl- $N$-acetylgalactosaminide glycosidase. The two enzyme proteins could be separated and purified by gel filtration ${ }^{1,2}$. Highly purified $N$-acetyl- $\beta$-D-hexosaminidase is inactive towards NANAfree OSM and large glycopeptides prepared from it.

When it was found ${ }^{3}$ that the digestive juice of Helix pomatia also contains the above specified hexosaminidases, it was decided to make a systematic investigation of their distribution in the animal kingdom.

1 A.S. Bhargava, E. Buddecke, E. Werries, and A. Gottschalk, Biochim. biophysica Acta [Amsterdam] 127, 457 [1966].

* Abbreviations: OSM, ovine submaxillary gland glycoprotein; NANA, $N$-acetylneuraminic acid; $\beta$-acetyl-glucosaminidase, $N$-acetyl- $\beta$-D-hexosaminidase; seryl- $N$-acetylgalactosaminidase, $O$-seryl- $N$-acetylgalactosaminide glycosidase.
For the experiments the animals shown in Table 1 were used. Of the invertebrates Mesostoma ehrenbergi was a gift from Professor V. Schwartz, Tübingen, the digestive juice of Helix pomatia was generously provided by l'Industrie Biologique Française, Gennevilliers (Seine), and Lumbricus terrestris was collected locally. The other invertebrates were gifts from the Stazione Zoologica at Naples and transported alive from there to Tübingen. The animals or specified organs of them were homogenized in a starmix (electrostar) for $2 \mathrm{~min}$ at $4^{\circ}$ in an appropriate volume of $0.1 \mathrm{M}$ citrate buffer, $p_{\mathrm{H}} 4.8$, contatining $0.1 \mathrm{M} \mathrm{NaCl}$. The homogenate was centrifuged at $15000 \mathrm{~g}$ for $20 \mathrm{~min}$ at $4^{\circ}$. The clear supernatant was used for assaying the enzymic activities. The substrates used in the assays were phenyl $N$-acetyl- $\beta$-D-glucosaminide and NANA-free OSM for $\beta$-acetylglucosaminidase and seryl- $N$-acetylgalactosaminidase respectively.

The $\beta$-acetylglucosaminidase assay contained 0.5 $\mathrm{ml}$ of $0.02 \mathrm{M}$ phenyl $N$-acetyl- $\beta$-D-glucosaminide in $0.1 \mathrm{M}$ citrate buffer, $p_{\mathrm{H}} 4.4,0.4 \mathrm{ml}$ distilled water and $0.1 \mathrm{ml}$ of the enzyme solution. Digestion at $37^{\circ}$ was carried out for 1 or $2 \mathrm{~h}$. The phenol released was determined according to Pugh, Leaback and $\mathrm{W}_{\text {ALKER }}{ }^{4}$. The seryl- $N$-acetylgalactosaminidase assay consisted of $0.2 \mathrm{ml}$ aqueous solution of NANAfree OSM (see reference ${ }^{1}$ ), containing $265 \mu \mathrm{g}$ ga-

2 E. Buddecke and E. Werries, Z. Naturforschg. 19 b, 798 [1964].

3 A. S. Bhargata and A. Gottschalk, Biochem. biophysic. Res. Commun. 24, 280 [1966].

${ }^{4}$ D. Pugh, D. H. Leaback, and P. G. W 464. [1957]. 


\begin{tabular}{|c|c|c|c|c|c|c|c|}
\hline \multirow[b]{2}{*}{ Name of animal } & \multicolumn{3}{|c|}{$N$-Acetyl- $\beta$-D-hexosaminidase } & \multicolumn{3}{|c|}{$O$-Seryl- $N$-acetylgalactosaminidase } & \multirow[b]{2}{*}{$\begin{array}{c}\text { Ratio } \\
a / b\end{array}$} \\
\hline & $\begin{array}{c}\text { Protein } \\
\text { per assay } \\
{[\mathrm{mg}]}\end{array}$ & $\begin{array}{l}\text { Milliunits } \\
\text { per assay }\end{array}$ & $\begin{array}{c}\text { Specific } \\
\text { activity } \\
\text { [milliunits] } \\
\text { (a) }\end{array}$ & $\begin{array}{l}\text { Protein } \\
\text { per assay } \\
{[\mathrm{mg}]}\end{array}$ & $\begin{array}{l}\text { Milliunits } \\
\text { per assay }\end{array}$ & $\begin{array}{c}\text { Specific } \\
\text { activity } \\
\text { [milliunits] } \\
\text { (b) }\end{array}$ & \\
\hline Adamsia palliata & 0.145 & 207.0 & 1428 & 0.232 & 0.081 & 0.349 & 4092 \\
\hline Mesostoma ehrenbergi & 0.179 & 16.6 & 92.7 & 0.268 & 0.207 & 0.772 & 120.1 \\
\hline Bugula avicularia & 0.113 & 181.0 & 1602 & 0.252 & 0.275 & 1.091 & 1468 \\
\hline Lumbricus terrestris & 0.584 & 115.0 & 196.9 & 1.168 & 0.242 & 0.207 & 951.2 \\
\hline \multicolumn{8}{|l|}{ Helix pomatia } \\
\hline (digestive juice) & 0.080 & 14.5 & 181.2 & 0.240 & 0.152 & 0.633 & 286.3 \\
\hline Pagurus prideauxi & 0.372 & 356.0 & 957.0 & 0.372 & 0.115 & 0.309 & 309.7 \\
\hline Ciona intestinalis & 0.102 & 334.0 & 3275 & 0.186 & 0.155 & 0.833 & 3932 \\
\hline Brachidanio albolineatus & 0.243 & 8.5 & 35.0 & 0.486 & 0.030 & 0.062 & 564.5 \\
\hline $\begin{array}{l}\text { Rana esculenta } \\
\text { (oviduct) }\end{array}$ & 0.050 & 8.3 & 166.0 & 0.500 & 0238 & 0.476 & 3487 \\
\hline Chick embryo & 0.117 & $\begin{array}{l}0.0 \\
5.3\end{array}$ & $\begin{array}{r}100.0 \\
45.3\end{array}$ & 0.293 & $\begin{array}{l}0.238 \\
0.024\end{array}$ & 0.082 & $\begin{array}{r}340.7 \\
552.4\end{array}$ \\
\hline Ox (spleen) & - & - & 10.0 & - & - & $\sim 0.05$ & $\sim 200$ \\
\hline
\end{tabular}

Table 1. Presence of $N$-acetyl- $\beta$-D-hexosaminidase and $O$-Seryl- $N$-acetylgalactosaminidase in invertebrates and vertebrates.

lactosamine (expressed as galactosamine hydrochloride), and $0.2 \mathrm{ml}$ of the enzyme solution ( $p_{\mathrm{H}} 4.8$ ). The digestion at $37^{\circ}$ in the presence of toluene proceeded for 20 to $40 \mathrm{~h}$. Suitable enzyme dilutions and digestion periods were found out in a preliminary experiment. With each assay a substrate and an enzyme control were run. The results are shown in Table 1. In Table 2 the phylogenetic classification ${ }^{5}$ of the animals tested is given.

\begin{tabular}{|c|c|c|}
\hline Phylum & $\begin{array}{l}\text { Sub-group } \\
\text { or class }\end{array}$ & Animal \\
\hline $\begin{array}{l}\text { Coelenterata } \\
\text { Parenchymia } \\
\text { Tentaculata ** } \\
\text { Articulata } \\
\text { Articulata } \\
\text { Mollusca } \\
\text { Chordata } \\
\text { Chordata }\end{array}$ & $\begin{array}{l}\text { Anthozoa } \\
\text { Plathelmintes } \\
\text { Bryozoa } \\
\text { Annelida } \\
\text { Arthropoda } \\
\text { Gastropoda } \\
\text { Tunicata } \\
\text { Vertebrata } \\
\text { Vertebrata } \\
\text { Vertebrata } \\
\text { Vertebrata }\end{array}$ & $\begin{array}{l}\text { Adamsia palliata } \\
\text { Mesostoma ehrenbergi } \\
\text { Bugula avicularia } \\
\text { Lumbricus terrestris } \\
\text { Pagurus prideauxi } \\
\text { Helix pomatia } \\
\text { Ciona intestinalis } \\
\text { Brachidanio albolinea- } \\
\text { tus (Pisces) } \\
\text { Rana esculenta } \\
\text { (Amphibia) } \\
\text { Chicken (white } \\
\text { leghorn) (Aves) } \\
\text { Ox (Mammalia) }\end{array}$ \\
\hline
\end{tabular}

Table 2. Phylogenetic classification * of the animals shown in Table 1. * The classification is based on A. KüHN's Grundriß der Allgemeinen Zoologie, 1961. ** One of the smaller Protostomia groups.

The figures in Table 1 refer to the supernatant of the homogenates. In case of Lumbricus terrestris about one-third of the specific activity of seryl- $N$ - acetylgalactosaminidase and about $40 \%$ of the specific activity of $\beta$-acetylglucosaminidase were found in the precipitate (see also ConchIE and $\mathrm{H}_{A Y}{ }^{6}$ ).

Ten $\mathrm{ml}$ of the crude enzyme preparation of chick embryo were applied to a Sephadex G-150 column $(150 \mathrm{~cm} \times 1.6 \mathrm{~cm})$ and fractionated $(2 \mathrm{ml}$ fractions $)$ as described previously ${ }^{1}$. The maximum of $\beta$-acetylglucosaminidase activity was in fraction 17 (specific activity $=555$ milliunits) and that of seryl- $N$-acetylgalactosaminidase activity in fraction 31 (specific activity $=0.373$ milliunits) .

Three $\mathrm{ml}$ of the crude enzyme preparation of Lumbricus terrestris were applied to a Sephadex G150 column $(100 \mathrm{~cm} \times 1.8 \mathrm{~cm})$ and fractionated as above. The maximum of seryl- $N$-acetylgalactosaminidase activity was in fraction 24 (specific activity $=9.25$ milliunits) and that of $\beta$-acetylglucosaminidase in fraction 30 (specific activity $=1690$ milliunits).

From the results presented it is evident that $\beta$ acetylglucosaminidase and seryl- $N$-acetylgalactosaminidase are present in the metazoa from Coelenterata to Mammals. The specific activity of the former enzyme is invariably several hundred or even a few thousand times higher than that of the latter. As previously shown for ox spleen and Helix pomatia, also the two enzyme proteins present in the homogenates of chick embryo and Lumbricus terrestris eluted from Sephadex columns in two sepa- 
rate peaks. It may be pointed out that the specific activities of the two enzymes recorded in Table 1 for various animals cannot be compared with each other since the supernatants of the homogenates contain only a portion of the total content of the respective hexosaminidases and since the instability of seryl. $N$-acetylgalactosaminidase ${ }^{3}$ may vary with the source. The relatively high specific activity of seryl$\mathrm{N}$-acetylgalactosaminidase of the oviduct of Rana esculenta was observed only in frogs shortly before spawning.

This investigation was supported by the D e u ts che Forschungsgemeins chaft. The authors wish to thank Professor V. Schwartz, Department of Zoology, University of Tübingen, for his valuable advice in the selection of the animals, and Dr. PETER Dohrs, Director of the Stazione Zoologica, Naples, for his generous cooperation in providing the maritime animals.

\title{
Some Immunochemical Characteristics of Sea Urchin Gametes
}

\author{
Stjepan Kečkeš ${ }^{1}$ and Mirjana Krajnović \\ Institute „Ruder Bošković“ and Institute of Marine Biology, Rovinj and Zagreb, Yugoslavia
}

(Z. Naturforschg. 22 b, 1032-1034 [1967] ; eingegangen am 27. Januar 1967)

\begin{abstract}
By double diffusion in agar the antigenic composition of four sea urchin species was examined. At least one common antigenic determinant was found in both gametes of all the four species investigated. Furthermore, in all eggs one and in all sperm another common "sex specific" antigenic determinant was established. In spite of the great number of antigenic determinants in each gamete extract, the existence of "species specific" determinants, common to sperm and eggs of one species, could not be determined with certainty.
\end{abstract}

Fertilization is at least partly due to the specific interaction between the chemical constituents of the sperm and egg surface. There are several methods for studying the chemical characteristics of the gametes, especially those which could play a certain role in fertilization. One of the best method is the immunochemical analysis introduced by TYLER ${ }^{2}$. This method, which with regard to specificity is far beyond the classical chemical analyses, uses the very sensitive and highly specific antigen-antibody reaction to discover the chemical composition of biological material.

Using the immunochemical analyses Perlmand ${ }^{3}$ found that in gamete extrats of Paracentrotus livi$d u s$, a common Mediterranean sea urchin, a great number of antigenically strongly different components are present. Furthermore, he showed that some of these components have a definite and specific effect when combined with the corresponding antisera. KöHLER and MEtz ${ }^{4}$ found a great number of different antigens in sperm extracts of various sea urchins and some of them proved to be associated to the sperm surface ${ }^{5}$.

1 Present address: Laboratory of Marine Radioactivity, International Atomic Energy Agency, Monaco.

2 A. TYLER, Physiol. Rev. 28, 180 [1948].

3 P. Perlmann, Experientia [Basel] 15, 41 [1959].

${ }^{4}$ K. Köhler and C. B. Metz, Biol. Bull. 118, 96 [1960].
It seemed worthwile to continue these investigations and compare the results obtained with those of the investigations on homologous and heterologous fertilization ${ }^{6-8}$.

\section{Material and Methods}

Gametes of four different sea urchin species, common along the west Istrian coast of the Adriatic sea (Paracentrotus lividus Lam., Arbacia lixula L., Sphaerechinus granularis Lam. and Psammechinus microtuberculatus Biv.) were used.

Freshly caught animals were opened by a circular cut with scissors and the ripe gonads were removed, separated according to sex and species, cut in smaller pieces and placed over dense gauze in a plastic funel. The extruded gametes were collected in bottles, cooled in ice and used freshly or freeze-dryed.

Antisera were obtained by hyperimmunization of rabbits with fresh or freeze-dryed gametes mixed with adjuvant ${ }^{9}$. Ten days after the last injection of antigen the blood of rabbits was collected, sera were separated by centrifugation and stored at $-20^{\circ} \mathrm{C}$ until use.

The following symbols were used for the antigens and the corresponding antisera:

5 G. P. F Fake and C. B. Metz, Biol. Bull. 123, 472 [1962].

6 B. E. Hagström and S. Lønning, Sarsia 4, 5 [1961].

7 S. KečKeš, Ph. D. thesis, Univ. of Zagreb 1962.

8 B. E. Hagström, Sarsia 17, 33 [1964].

9 J. Freund and K. McDermott, Proc. Soc. exp. Biol. Med. 49, 548 [1942]. 